\title{
Thermal properties of Conilon coffee fruits
}

\author{
Casanova, Pedro ${ }^{1}$, Corrêa, Paulo C. ${ }^{2}$, Solís, Kattia ${ }^{3}$, Campos, Julio C. C. ${ }^{4}$ \\ ${ }^{I}$ (Instituto de Investigaciones de Ingeniería (INII). Universidad de Costa Rica. Apdo. postal: 3620-60. San \\ Pedro de Montes de Oca, San José, Costa Rica.) \\ ${ }_{2}^{2}$ (Centro Nacional de Treinamento em Armazenagem (CENTREINAR). Universidade Federal de Viçosa, Viçosa, \\ $M G$, Brazil.) \\ ${ }^{3}$ (Escuela de Ingeniería Agrícola. Universidad de Costa Rica, Apdo. postal: 3620-60. San Pedro de Montes de \\ Oca, San José, Costa Rica.) \\ ${ }^{4}$ (Departamento de Engenharia Mecânica. Universidade Federal de Viçosa, Viçosa, MG, Brazil.)
}

\begin{abstract}
The specific heat, thermal conductivity and diffusivity of coffee fruits (Coffea Canephora) from the clone 32 of clonal variety EMCAPA 8131 were determined for moisture content ranging from 0.134 to 1.454 d.b. for unripe fruits and from 0.133 to 1.634 d.b. for ripe fruits (cherries). The specific heat was determined by the method of mixtures and the values from 1.442 to $3.298 \mathrm{~kJ} \mathrm{~kg}^{-1} \mathrm{~K}^{-1}$ and 1.431 to $3.615 \mathrm{~kJ} \mathrm{~kg}^{-1} \mathrm{~K}^{-1}$ were obtained for the unripe and cherry fruits, respectively and increased linearly with increasing moisture content. The thermal conductivity was measured by transient method with linear source of heat and its behaviour is similar to that of specific heat, ranging from 0.117 to $0.204 \mathrm{~W} \mathrm{~m}^{-1} \mathrm{~K}^{-1}$ and 0.108 to $0.216 \mathrm{~W} \mathrm{~m}^{-1} \mathrm{~K}^{-1}$ for unripe and cherry coffee, respectively. The thermal diffusivity values calculated by the indirect method from the results of specific heat and thermal conductivity ranged from $1.671 \times 10^{-7}$ to $1.044 \times 10^{-7} \mathrm{~m}^{2} \mathrm{~s}^{-1}$ and $1.594 \times 10^{-7}$ to $1.047 \times 10^{-7} \mathrm{~m}^{2} \mathrm{~s}^{-1}$ for unripe and cherry coffees, showing a decreasing linear ratio as moisture content increased.
\end{abstract}

Keywords: - Coffea Canephora; thermal conductivity; specific heat; thermal diffusivity.

\section{INTRODUCTION}

Knowledge on the physical and thermal properties of coffee is essential for research on phenomena of heat and mass transfers during drying process.

According to [1], [2] and [3] physical and thermal properties of grains are important in drying processes due to flow restrictions in heat and mass transfers. Each thermal property has a significant effect on the rate of drying of a single grain or of a grain layer [4].

Appropriate harvest, handling and processing operations are especially important to determine the final quality of a product, which affects the markets for the product. The knowledge of the thermal properties of agricultural products is necessary for the design of a new operation unit or for the analysis of processes such as drying and storage, as well as the prediction and control of many changes food undergoes during thermal and preservation processes. Similar studies show that moisture content has considerable effect on the thermal properties of agricultural materials and food [5-9].

The application of engineering principles to biological systems is often challenging due to inadequate databases of biological properties [10]. Data about these properties are useful for the management of agricultural materials, drying, processing, storage, equipment design and control [2]. Often, the physical properties of biological materials are dependent on the moisture content, which would affect the performance and the adjustment of the equipment. Therefore, the effect of moisture content on the physical properties of agricultural materials is an important consideration in post-harvest management and operations for the processing of food and agricultural products. Knowledge of the thermal properties of agricultural materials is essential for modeling, optimization and design of practices and processing equipment for operations based on heat treatment, including dehydration, bleaching, cooking, heating, cooling, vaporizing and freezing [11].

Thermal conductivity is defined as the ratio between the density of heat flux and temperature gradient in the material. Determining the ability to which an agricultural product conducts heat is necessary to predict or control the flow of heat in this product during processing operations, such as steady and transient. Thermal conductivity can be expressed based on Fourier's law of heat conduction, as presented below:

$$
k=\frac{q}{A} \frac{d x}{d t}
$$

Methods for determining thermal conductivity can be classified into two categories: steady and transient state methods of heat transfer [1]. The steady state method requires a long time to be completed and there may be moisture content migration, which may introduce significant errors of measurement [1], [12], [13]. 
Both difficulties can be avoided by using the transient method of heat flow to determine the thermal conductivity of different grains.

The methods of linear heat source and temperature sensor have been used to determine the thermal conductivity of agricultural materials.

The thermal conductivity determination through the method of temperature sensor in thermal transient state was used in avocado pulp [14], fresh seafood, powdered squid, octopus and squid king [15], palm fruits [16], banana, apple and papaya [17] and potato cubes [18].

The method of linear heat source in transient state has been used by many researchers to determine the thermal conductivity of grains and seeds, such as barley, lentils and peas [11], cassava, sweet potato and plantain chips [19], parchment coffee [20] and borage seed [21]. There is consensus among researchers that conductivity increases as moisture content increases.

Knowledge on specific heat is essential to determine the amount of energy required in the process of heating or cooling in agricultural products. It is defined as the amount of heat required to raise the temperature of a body by $1^{\circ} \mathrm{C}$ per unit mass without changing its state.

The mixing method is a versatile method used by various researchers to determine the specific heat of granular materials. The specific heat of agricultural products rises with increasing moisture content [6]. Singh (2001) [22] studied the specific heat of cumin seeds and found values for specific heat ranging from 1.330 to $3090 \mathrm{~kJ} \mathrm{~kg}^{-1} \mathrm{~K}^{-1}$ due to temperature increase, from -70 to $50^{\circ} \mathrm{C}$, and the moisture content values ranging from 1.8 to 20.5 d.b. Aviara (2001) [8] determined the specific heat of shea fruit depending on moisture content and temperature (3.32 to 20.70 d.b. and 30 to $90^{\circ} \mathrm{C}$ ). They concluded that both have significant influence on agricultural materials. Subramanian (2003) [23] determined the specific heat of millet grain and flour, from 1.33 to $2.40 \mathrm{~kJ} \mathrm{~kg}^{-1} \mathrm{~K}^{-1}$, for moisture contents ranging from 0.11 to $0.43 \mathrm{~d}$.b. The mixing method was used by [24] to estimate the specific heat of maize; [20] used it for coffee in parchment. The specific heat rates of grass [12], fungi [25] and pistachio [26] were also determined by this method. Jaramillo (1989) [27] and Montoya (1989) [28] determined the specific heat of parchment coffee. Their results showed that it is not simple to relate the specific heat with grain moisture content. Jaramillo (1989) [27] found a nonlinear relationship between specific heat and grain moisture content, while [28] found linear correlation.

To complete the study on the thermal properties of agricultural materials, it is convenient to use the ratio between the ability of a material to transport energy and to store energy. It is the thermal diffusivity, defined as:

$$
\alpha=\frac{k}{\rho \cdot C_{p}}
$$

Equation (2) helps estimating the time required to transport energy in the processes of heating, cooling, freezing and cooking. On the fact that the lack of information in the literature for Conilon coffee, this study aimed to determine the main thermal properties: specific heat, thermal diffusivity and conductivity, depending on the moisture content of the product.

\section{NOMENCLATURE}

$\begin{array}{ll}\mathrm{Cp}_{\mathrm{H} 2 \mathrm{O}} & \text { Specific heat of water }\left(\mathrm{kJ} \mathrm{kg}^{-1} \mathrm{~K}^{-1}\right) \\ \mathrm{C} & \text { Constant of the calorimeter }\left(\mathrm{kJ} \mathrm{K}^{-1}\right) \\ \mathrm{k} & \text { Thermal conductivity }\left(\mathrm{W} \mathrm{m}^{-1} \mathrm{~K}^{-1}\right) \\ \text { mac } & \text { Hot water mass }(\mathrm{kg}) \\ \mathrm{mp} & \text { Product mass }(\mathrm{kg}) \\ \mathrm{q} & \text { Heat }\left(\mathrm{W} \mathrm{m}^{-1}\right) \\ \mathrm{Teq} & \text { Temperature of balance }\left({ }^{\circ} \mathrm{C}\right) \\ \mathrm{Tac} & \text { Temperature of hot water }\left({ }^{\circ} \mathrm{C}\right) \\ \mathrm{Tp} & \text { Temperature of the product }\left({ }^{\circ} \mathrm{C}\right) \\ \mathrm{t} & \text { Time }(\mathrm{s}) \\ \mathrm{Mc} & \text { Moisture content }(\text { d.b. }) \\ \alpha & \text { Diffusivity }\left(\mathrm{m}^{2} \mathrm{~s}^{-1}\right) \\ \rho & \text { Bulk density }\left(\mathrm{kg} \mathrm{m} \mathrm{m}^{-3}\right) \\ \delta & \text { Measurement uncertainty }\end{array}$

\section{MATERIAL AND METHODS}

This work was developed in the Laboratory of Physical Properties and Quality Evaluation, in the Centro Nacional de Treinamento em Armazenagem - CENTREINAR (National Center for Storage Training), of the Universidade Federal de Viçosa, Minas Gerais, Brazil. Coffee fruits from the Coffea Canephora species, 
clone 32 of clonal variety EMCAPA 8131 have been used. They were collected from an experimental farm of EPAMIG, in the municipality of Leopoldina. Unripe and ripe fruits have been used in the experiment.

The drying process was carried out in a forced ventilation oven at temperature of $60 \pm 3^{\circ} \mathrm{C}$, from where samples were obtained. They presented moisture contents ranging from 0.134 to 1.454 d.b. for the unripe beans and 0.133 to 1.634 d.b. for the ripe fruits. The moisture content of the product has been determined by the oven method, at the temperature of $105 \pm 3^{\circ} \mathrm{C}$, with three replicates [29].

All tests were performed for five moisture contents, considering two groups of coffee fruits tested in three replicates for each point in the study.

Thus, tools were used to provide the values of thermal properties for agricultural materials, specific heat, thermal conductivity and bulk density.

A mixing calorimeter was used to determine the specific heat of the mass of coffee fruits [5], [6] . The specific heat of the product is determined by the following equation [30]:

$$
C_{p}=\frac{C p_{H 2 O} \cdot m_{a c}\left(T_{a c}-T_{e q}\right)+C\left(T_{a c}-T_{e q}\right)}{m_{p}\left(T_{e q}-T_{p}\right)}
$$

The method of theoretically infinite cylinder was used to determine thermal conductivity like [5], [6]. The thermal conductivity was determined through (4), [30]:

$$
k=\frac{q}{4 \pi L\left(T_{1}-T_{2}\right)} \ln \left(\frac{t_{2}}{t_{1}}\right)
$$

The bulk density was determined by filling a cylindrical container with $500 \mathrm{ml}$ of coffee fruits from a height of $15 \mathrm{~cm}$ at a constant rate and then weighting the contents. The ratio between the mass and volume of the coffee container was defined as bulk density.

With the values of thermal properties, (2) was used to characterize the thermal diffusivity of the product.

Uncertainty is a fact in engineering. Therefore, it is necessary to know the uncertainty of the data, usually defined as the range within which the researcher is 95 confident that the true value lies.

The method described by [31] was used for the analysis of the uncertainty in the experimental results. This method is based on careful specification of the various uncertainties of the experimental primary measurements. Assuming that a measured variable " $R$ " is a function of several independent primary variables $\mathrm{x}_{1}$, $\mathrm{x}_{2}, \ldots, \mathrm{x}_{\mathrm{n}}$, then, we have:

$\mathrm{R}=\mathrm{R}\left(\mathrm{x}_{1}, \mathrm{x}_{2}, \ldots, \mathrm{x}_{\mathrm{n}}\right)$

Assuming that $\mathrm{w}_{1}, \mathrm{w}_{2}, \ldots, \mathrm{w}_{\mathrm{n}}$, are the individual uncertainties of the respective independent primary variables $\mathrm{x}_{1}, \mathrm{x}_{2}, \ldots ., \mathrm{x}_{\mathrm{n}}$, this method proposes that the uncertainty resulting from the final dimension " $\mathrm{w}_{\mathrm{R}}$ " should be calculated by the following equation:

$$
w_{R}=\left[\left(\frac{\partial R}{\partial x_{1}} \cdot w_{1}\right)^{2}+\left(\frac{\partial R}{\partial x_{2}} \cdot w_{2}\right)^{2}+\cdots+\left(\frac{\partial R}{\partial x_{n}} \cdot w_{n}\right)^{2}\right]^{1 / 2}
$$

The "ESS - Engineering Equation Solver" software system for engineering, "Uncertain Propagation" tool, which is based on the method described by [31], was used to minimize the mathematical effort to analyse the various uncertainties of experimental results.

The adjusted equations were compared through the model identity test to verify the null hypothesis that the equations are statistically equal. The identity test of the model is based on the difference between the sum of the parameter squares for the complete model and the sum of parameter squares for the reduced model [32]. Initially, the test was conducted for all equations adjusted for each relationship. Then, the identity test of the model was used to compare each equation. In other words, the test was applied for every treatment, both unripe and cherry.

\section{RESULTS AND DISCUSSION}

The methodology reported by [32] to identify the regression models demonstrated that the models found for specific heat, thermal conductivity and thermal diffusivity of unripe and cherry coffee fruits are identical. Therefore, it is possible to obtain a common or reduced model with all data (Table 1). 
The specific heat of coffee fruits was determined between 1.431 and $3.615 \mathrm{~kJ} \mathrm{~kg}^{-1} \mathrm{~K}^{-1}$ for a range of moisture content from 0.133 to 1.634 d.b., (Tables 2 and 3). The regression analysis revealed a linear relationship between the moisture content and specific heat (Table 1). It demonstrates that specific heat increases as moisture content of coffee fruits increases (Figure 1). This behaviour is very similar to that found by other researchers. Chandrasekar (1999) [33] determined the specific heat of Robusta parchment coffee for moisture content ranging from 0.1 to $0.35 \mathrm{~d}$.b. and obtained values between 1.04 and $2.36 \mathrm{~kJ} \mathrm{~kg}^{-1} \mathrm{~K}^{-1}$. In regard to Arabica coffee in parchment with moisture content in the range of 0.12 and 0.44 d.b., the specific heat values were between 0.78 and $2.18 \mathrm{~kJ} \mathrm{~kg}^{-1} \mathrm{~K}^{-1}$. Afonso Júnior (2002) [5] assigned values between 1.2146 and $2.5251 \mathrm{~kJ}$ $\mathrm{kg}^{-1} \mathrm{~K}^{-1}$ for Arabica coffee variety Catuaí, for dry cherry; between 1.2254 and $2.4653 \mathrm{~kJ} \mathrm{~kg}^{-1} \mathrm{~K}^{-1}$ for husked cherry; and between 1.1290 and $2.3848 \mathrm{~kJ} \mathrm{~kg}^{-1} \mathrm{~K}^{-1}$ for parchment coffee. Borém et al (2002) [7] studied five varieties of Arabica coffee in parchment and found variation in specific heat from 1.0 to $3.0 \mathrm{~kJ} \mathrm{~kg}^{-1} \mathrm{~K}^{-1}$, for moisture contents ranging between 0.1 and 0.95 d.b. Other authors found similar data while determining the specific heat of different products [8], [20-22], [34].

Table 1. Regression equations of specific heat, thermal conductivity and thermal diffusivity for unripe and cherry Conilon coffee and common model.

\begin{tabular}{cllc}
\hline Treatment & \multicolumn{1}{c}{ Thermal property } & \multicolumn{1}{c}{ Model $\mathbf{Y}=\mathbf{a X}+\mathbf{b}$} & $\mathbf{R}^{\mathbf{2}}$ \\
\hline \multirow{2}{*}{ Cherry } & Specific heat $\mathrm{C}_{\mathrm{p}}$ & $1.4392 \mathrm{Mc}+1.2643$ & 0.993 \\
& Thermal conductivity, $\mathrm{k}$ & $0.0705 \mathrm{Mc}+0.1083$ & 0.953 \\
& Thermal diffusivity, $\alpha$ & $-3,4246 \mathrm{E}-008 \mathrm{Mc}+1,5921 \mathrm{E}-007$ & 0.958 \\
\hline \multirow{2}{*}{ Unripe } & Specific heat $\mathrm{C}_{\mathrm{p}}$ & $1.4225 \mathrm{Mc}+1.2017$ & 0.994 \\
& Thermal conductivity, $\mathrm{k}$ & $0.0602 \mathrm{Mc}+0.1203$ & 0.911 \\
& Thermal diffusivity, $\alpha$ & $-4,9614 \mathrm{E}-008 \mathrm{Mc}+1,7180 \mathrm{E}-007$ & 0.957 \\
\hline \multirow{2}{*}{ Common } & Specific heat, $\mathrm{C}_{\mathrm{p}}$ & $1.4386 \mathrm{Mc}+1.2307$ & 0.991 \\
& Thermal conductivity, $\mathrm{k}$ & $0.0659 \mathrm{Mc}+0.1142$ & 0.922 \\
& Thermal diffusivity, $\alpha$ & $-4,1108 \mathrm{E}-008 \mathrm{Mc}+1,6508 \mathrm{E}-007$ & 0.924 \\
\hline
\end{tabular}

$\mathrm{R}^{2}$ : coefficient of determination; Mc: Moisture content.

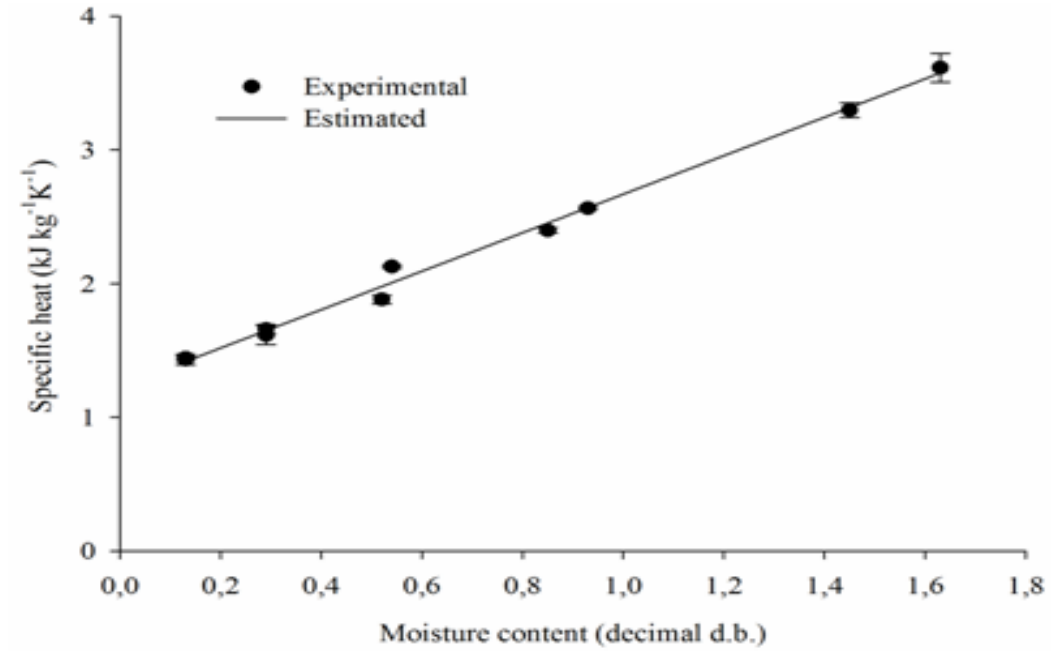

Figure 1. Experimental and estimated values of specific heat, according to the moisture content of Conilon coffee fruits.

Table 2. Statistical analysis and uncertainties of the thermal properties of cherry fruits of Conilon coffee.

\begin{tabular}{|c|c|c|c|c|c|c|c|c|c|c|}
\hline \multirow{2}{*}{$\begin{array}{c}\text { Mc } \\
\text { (d.b.) }\end{array}$} & \multicolumn{3}{|c|}{$\mathbf{k},\left(\mathbf{W} \mathbf{m}^{-1} \mathbf{K}^{-1}\right)$} & \multirow{2}{*}{$\square \mathbf{k}$} & \multicolumn{3}{|c|}{$\mathrm{Cp},\left(\mathrm{kJ} \mathrm{kg}^{-1} \mathrm{~K}^{-1}\right)$} & \multirow{2}{*}{$\square \mathbf{C p}$} & \multirow{2}{*}{$\left(\mathrm{m}^{2} \mathbf{s}^{-1}\right)$} & \multirow{2}{*}{$\square \square$} \\
\hline & Mean & Std.Dv. & Std.Err. & & Mean & Std.Dv. & Std.Err. & & & \\
\hline 1,634 & 0,216 & 0,0099 & 0,0057 & 0,006056 & 3,615 & 0,1073 & 0,0620 & 0,03782 & $1,047 \mathrm{E}-07$ & $3,12 \mathrm{E}-09$ \\
\hline 0,930 & 0,184 & 0,0029 & 0,0017 & 0,003088 & 2,564 & 0,0109 & 0,0063 & 0,03044 & $1,281 \mathrm{E}-07$ & 2,63E-09 \\
\hline 0,535 & 0,155 & 0,0015 & 0,0009 & 0,002603 & 2,128 & 0,0108 & 0,0062 & 0,02962 & $1,339 \mathrm{E}-07$ & $2,26 \mathrm{E}-09$ \\
\hline 0,293 & 0,127 & 0,0026 & 0,0015 & 0,001821 & 1,658 & 0,0345 & 0,0199 & 0,02715 & $1,492 \mathrm{E}-07$ & $3,24 \mathrm{E}-09$ \\
\hline 0,133 & 0,108 & 0,0014 & 0,0008 & 0,001597 & 1,431 & 0,0389 & 0,0224 & 0,02469 & $1,594 \mathrm{E}-07$ & $3,63 \mathrm{E}-09$ \\
\hline
\end{tabular}


Thermal properties of Conilon coffee fruits

Table 3. Statistical analysis and uncertainties of the thermal properties of unripe fruits of Conilon coffee.

\begin{tabular}{|c|c|c|c|c|c|c|c|c|c|c|}
\hline \multirow{2}{*}{$\begin{array}{c}\text { Mc } \\
\text { (d.b.) }\end{array}$} & \multicolumn{3}{|c|}{$\mathbf{k},\left(\mathbf{W} \mathbf{~ m}^{-1} \mathbf{K}^{-1}\right)$} & \multirow{2}{*}{$\delta \mathrm{k}$} & \multicolumn{3}{|c|}{$\mathrm{C}_{\mathbf{p}},\left(\mathrm{kJ} \mathrm{kg}^{-1} \mathrm{~K}^{-1}\right)$} & \multirow{2}{*}{$\delta_{\mathrm{Cp}}$} & \multirow{2}{*}{$\underset{\left(m^{2} s^{-1}\right)}{\mathbf{a}}$} & \multirow{2}{*}{$\delta \alpha$} \\
\hline & Mean & Std.Dv. & Std.Err. & & Mean & Std.Dv. & Std.Err. & & & \\
\hline 1,454 & 0,204 & 0,0080 & 0,0046 & 0,003852 & 3,298 & 0,0547 & 0,0316 & 0,03612 & $1,044 \mathrm{E}-07$ & $2,28 \mathrm{E}-09$ \\
\hline 0,855 & 0,172 & 0,0067 & 0,0039 & 0,002502 & 2,399 & 0,0186 & 0,0107 & 0,03006 & -07 & $2,30 \mathrm{E}-09$ \\
\hline 0,524 & 0,163 & 0,0068 & 0,0039 & 0,002409 & 1,883 & 0,0317 & 0,0183 & 0,02921 & $1,461 \mathrm{E}-07$ & $3,13 \mathrm{E}-09$ \\
\hline 0,287 & 0,141 & 0,0053 & 0,0031 & 0,00209 & 1,614 & 0,0713 & 0,0412 & 0,0262 & $1,6 \mathrm{E}-07$ & $3,51 E-09$ \\
\hline 0,134 & 0,117 & 0,0023 & 0,0013 & 0,001979 & 1,442 & 0,0139 & 0,0080 & 0,02391 & $1,671 \mathrm{E}-07$ & $3,95 \mathrm{E}-09$ \\
\hline
\end{tabular}

The thermal conductivity of coffee fruit was $0.108-0.216 \mathrm{~W} \mathrm{~m} \mathrm{~m}^{-1}$ for moisture content ranging from 0.133 to 1.634 d.b., (Table 2 and 3). Variation of thermal conductivity according to moisture content rate is shown in figure 2. It shows that thermal conductivity increases linearly with increasing moisture content. Similar behaviour was observed by [5] for Arabica coffee variety Catuaí, when values between 0.0843 and $0.1415 \mathrm{~W} \mathrm{~m}^{-1} \mathrm{~K}^{-1}$ were assigned for dry cherry; between 0.0934 and $0.1735 \mathrm{~W} \mathrm{~m}^{-1} \mathrm{~K}^{-1}$ for husked cherry; and between 0.1033 and $0.1762 \mathrm{~W} \mathrm{~m}^{-1} \mathrm{~K}^{-1}$ for coffee in parchment. Borém et al (2002) [7] assigns values of thermal conductivity between 0.10 and $0.20 \mathrm{~W} \mathrm{~m}^{-1} \mathrm{~K}^{-1}$, while [33] obtained values between 0.10 and $0.20 \mathrm{~W} \mathrm{~m}^{-1} \mathrm{~K}^{-1}$ for Robusta coffee in parchment, with moisture content ranging from 0.11 to 0.35 d.b.; and obtained specific heat values between 0.07 and $0.16 \mathrm{~W} \mathrm{~m}^{-1} \mathrm{~K}^{-1}$ for Arabica coffee in parchment, with moisture content between 0.12 and 0.44 d.b.

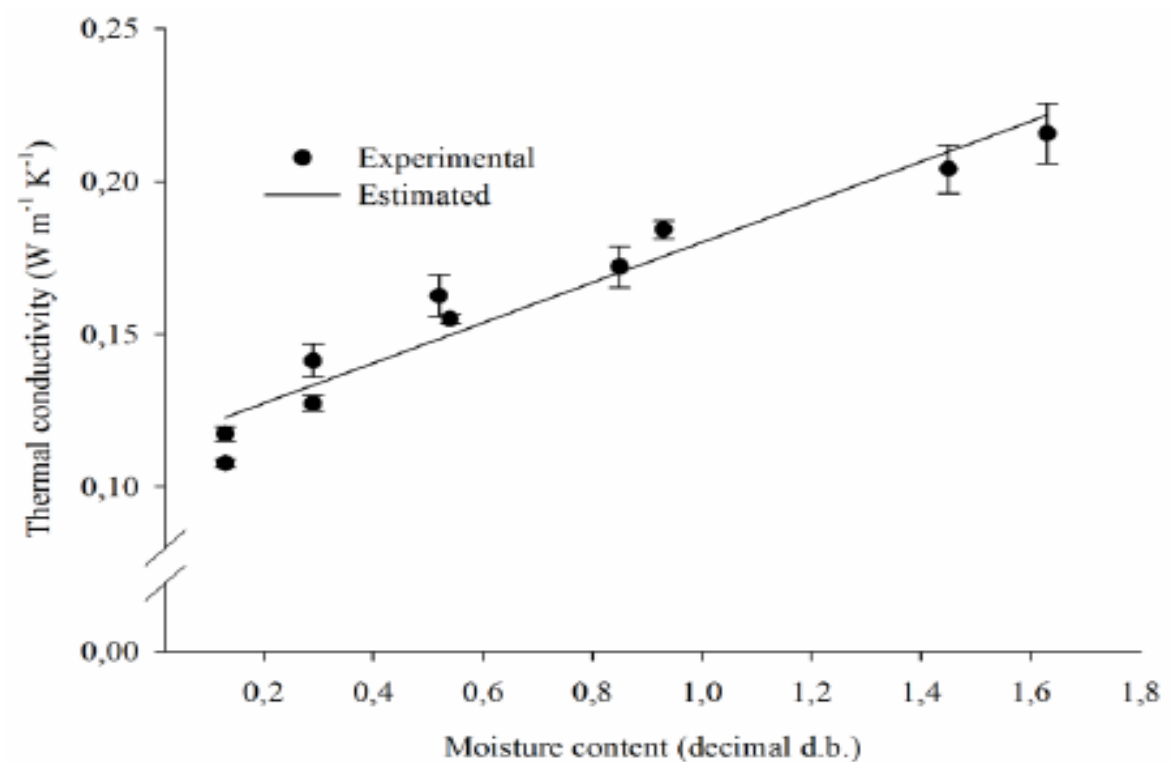

Figure 2. Experimental and estimated values of thermal conductivity according to the moisture content of Conilon coffee fruits.

Similar variations have been recorded for the thermal conductivity of maize, sunflower, wheat and barley [35], pumpkin seeds [34], rice flour [36], shea fruits [8], borage seed [21], cumin seeds [22] and parchment coffee [20], among others.

The thermal diffusivity values were determined by applying equation 2 for each level of moisture content studied (Table 2 and 3). The thermal diffusivity for coffee fruits was determined between $1.671 \times 10^{-7}$ and $1.044 \times 10^{-7} \mathrm{~m}^{2} \mathrm{~s}^{-1}$ for moisture content ranging from 0.133 to $1.634 \mathrm{~d} . \mathrm{b}$. A decreasing ratio of the thermal diffusivity with the growth of moisture content was determined by regression analysis (Figure 3). Similar behaviour was recorded in other studies, which determined the thermal properties of different species and varieties of coffee. Chandrasekar (1999) [33] stands out among them for Robusta coffee in parchment. With moisture content ranging from 0.11 to 0.35 d.b., it obtained values between $2.36 \times 10^{-7}$ and $1.69 \times 10^{-7} \mathrm{~m}^{2} \mathrm{~s}^{-1}$; and for Arabica coffee in parchment, with moisture content ranging between 0.12 and 0.44 d.b., specific heat values between $2.08 \times 10^{-7}$ and $1.44 \times 10^{-7} \mathrm{~m}^{2} \mathrm{~s} 1$ were found. For the five types of coffee studied, [7] found thermal diffusivity decrease with increasing moisture for a range of values between $1.0 \times 10^{-7} \mathrm{~m}^{2} \mathrm{~s}^{-1}$ and $3.0 \times$ $10^{-7} \mathrm{~m}^{2} \mathrm{~s}^{-1}$. Pabis (1988) [5] records for Arabica coffee, variety Catuaí, ranged between $1.069 \times 10^{-7}$ and $1.544 \times$ $10^{-7} \mathrm{~m}^{2} \mathrm{~s}^{-1}$ for dry cherry; between $1.357 \times 10^{-7}$ and $1.699 \times 10^{-7} \mathrm{~m}^{2} \mathrm{~s}^{-1}$ for husked cherry; and between $1.344 \times$ $10^{-7}$ and $2.078 \times 10^{-7} \mathrm{~m}^{2} \mathrm{~s}^{-1}$ for coffee in parchment. 


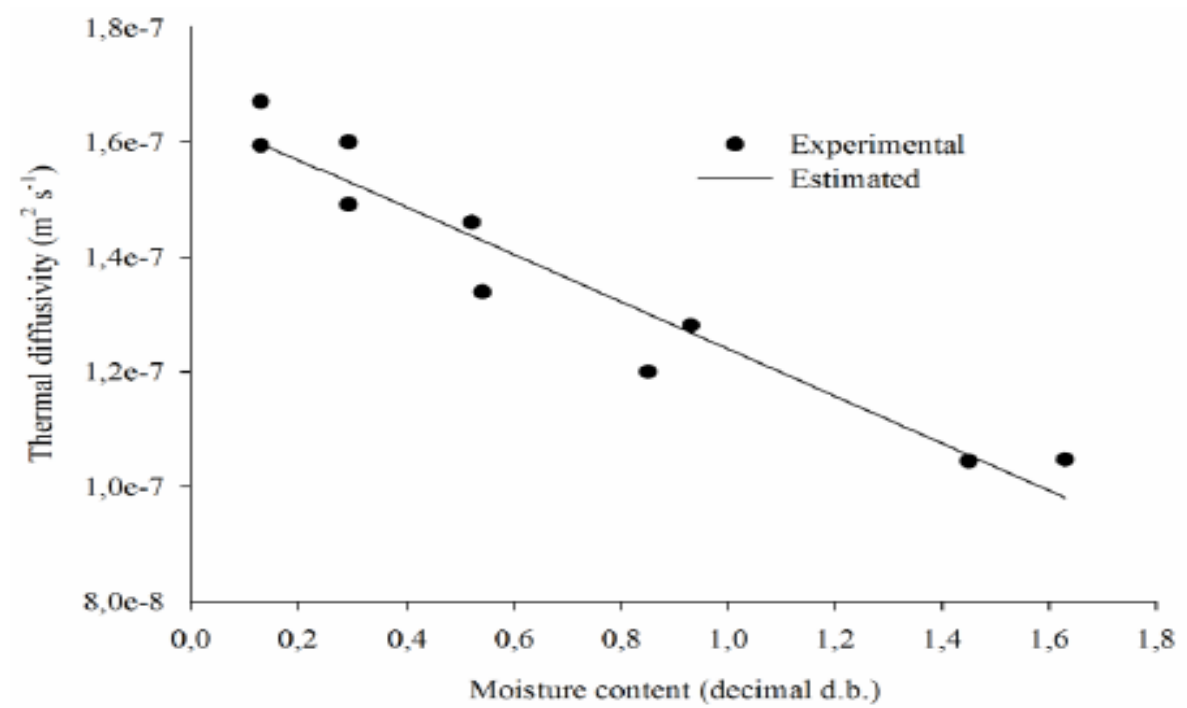

Figure 3. Experimental and estimated values of thermal diffusivity, according to the moisture content of Conilon coffee fruits.

Similar behaviour was recorded in the determination of thermal diffusivity of rice flours [36], pumpkin seeds [34], borage seed [21] and peanuts [6].

\section{CONCLUSIONS}

Thermal properties of coffee fruits from Coffea canephora, clone 32 of clonal variety EMCAPA 8131, such as thermal conductivity, thermal diffusivity and specific heat were determined for five levels of moisture content and two ripening stages (unripe and cherry).

The specific heat, thermal conductivity and thermal diffusivity for moisture content ranging from 0.133 to 1.634 d.b. were determined between 1.431 and $3.615 \mathrm{~kJ} \mathrm{~kg}^{-1} \mathrm{~K}^{-1} ; 0.108$ and $0.216 \mathrm{~W} \mathrm{~m}^{-1} \mathrm{~K}^{-1}$; and $1.044 \times 10^{-7}$ to $1.671 \times 10^{-7} \mathrm{~m}^{2} \mathrm{~s}^{-1}$, respectively, for the Conilon coffee fruits getting a common regression model for each of them.

It was determined that the thermal properties of Conilon coffee depend on the moisture content. The specific heat and thermal conductivity of fruits of Conilon coffee increases with increasing moisture content, whereas thermal diffusivity decreases with increasing moisture content.

\section{ACKNOWLEDGEMENTS}

The authors gratefully acknowledge the financial support of Coordenação de Aperfeiçoamento de Pessoal de Nível Superior (CAPES), Universidad de Costa Rica (UCR), Ministerio de Ciencia y Tecnología (MICIT) and Consejo Nacional para Investigaciones Científicas y Tecnológicas (CONICIT) of Costa Rica.

\section{REFERENCES}

[1] N. N. Mohsenin, Thermal properties of foods and agricultural materials. New York: Gordon and Breach, 1980 , p. 407.

[2] N. N. Mohsenin, Physical properties of plant and animal materials. New York: Gordon and Breach Publishers, 1986, p. 841.

[3] S. Pabis, D. S. Jayas, and S. Cenkowski, Grain drying: theory and practice. New York: John Wiley \& Sons, Inc, 1998, p. 303.

[4] D. B. Brooker, F. W. Bakker-Arkema, and C. W. Hall, Drying and Storage of Grains and Oilseeds. New York: Van Nostrand Reinhold, 1992, p. 450.

[5] P. Afonso Júnior, P. Corrêa, and F. Pinto, "Propriedades termofísicas dos frutos e sementes de café : determinação e modelagem.," Revista Brasileira de Armazenamento, no. 4, pp. 09-15, 2002.

[6] V. S. P. Bitra, S. Banu, P. Ramakrishna, G. Narender, and A. R. Womac, "Moisture dependent thermal properties of peanut pods, kernels, and shells," Biosystems Engineering, vol. 106, no. 4, pp. 503-512, Aug. 2010.

[7] F. M. Borém, R. C. D. M. S. Ribeiro, P. C. Corrêa, and R. G. F. Pereira, "Propriedades térmicas de cinco variedades de café cereja descascado," Revista Brasileira de Engenharia Agrícola e Ambiental, vol. 6, no. 3, pp. 475-480, Dec. 2002. 
[8] N. . Aviara and M. . Haque, "Moisture dependence of thermal properties of sheanut kernel," Journal of Food Engineering, vol. 47, no. 2, pp. 109-113, Feb. 2001.

[9] C. S. Chang, "Thermal conductivity of wheat, corn, and grain sorghum as affected by bulk density and moisture content.," Transactions of the ASAE, vol. 29, no. 5, pp. 1447-1450, 1986.

[10] S. K. Sharma, R. K. Dubey, and C. K. Teckchandani, "Engineering properties of black gram, soybean and green gram.," in Proceedings of the Indian Society of Agricultural Engineers, 1985, pp. 181-185.

[11] K. Alagusundaram, D. S. Jayas, W. E. Muir, and N. D. G. White, "Thermal conductivity of bulk barley, lentils and peas," Transactions of the ASABE, vol. 34, no. 4, pp. 1784-1788, 1991.

[12] S. K. Dutta, V. K. Nema, and R. K. Bhardwaj, "Thermal properties of gram," Journal of Agricultural Engineering Research, vol. 39, no. 4, pp. 269-275, Apr. 1988.

[13] E. A. Kazarian and C. W. Hall, "Thermal properties of grains," Transactions of the ASAE, vol. 8, no. 1, pp. 33-37, 1965.

[14] M. Valente and J. Nicolas, "Thermal conductivity of avocado pulp," in Engineering and food. Volume 1. Physical properties and process control, London: Elsevier, 1990, pp. 432-440.

[15] M. S. Rahman, P. L. Potluri, and A. Varamit, "Thermal conductivities of fresh and dried seafood powders," Transactions of the ASAE, vol. 34, no. 1, pp. 217-220, 1991.

[16] S. . Obetta, "Studies on some physico-thermal properties of palm kernel," Journal of food science and technology, vol. 37, no. 3, pp. 245-249, 2000.

[17] R. Mathur and S. S. Lele, "Thermal conductivity measurement technique vis-a-vis quality of fruit," Journal of food science and technology, vol. 38, no. 5, pp. 484-486, 2001.

[18] S. Mukherjee and P. K. Chattopadhyay, "The influence of moisture content and temperature on thermal properties of potato," Journal of food science and technology, vol. 39, no. 2, pp. 134-138, 2002.

[19] D. N. Njie, T. R. Rumsey, and R. P. Singh, "Thermal properties of cassava, yam and platain," Journal of Food Engineering, vol. 37, no. 1, pp. 63-76, Jun. 1998.

[20] L. R. Perez-Alegria, H. J. Ciro, and L. C. Abud., "Physical and thermal properties of parchment coffee bean," Transactions of the ASAE, vol. 44, no. 6, pp. 1721-1726, 2001.

[21] W. Yang, S. Sokhansanj, J. Tang, and P. Winter, "Determination of thermal conductivity specific heat and thermal diffusivity of borage seeds," Biosystems Engineering, vol. 82, no. 2, pp. 169-176, Jun. 2002.

[22] K. K. Singh and T. K. Goswami, "Thermal properties of cumin seed," Journal of Food Engineering, vol. 45, no. 4, pp. 181-187, Sep. 2000.

[23] S. Subramanian and R. Viswanathan, "Thermal Properties of Minor Millet Grains and Flours," Biosystems Engineering, vol. 84, no. 3, pp. 289-296, Mar. 2003.

[24] R. C. Verma and S. Prasad, "Mechanical and thermal properties of maize," Journal of Food Science and Technology, vol. 37, no. 5, pp. 500-505, 2000.

[25] M. Shrivastava and A. . Datta, "Determination of specific heat and thermal conductivity of mushrooms (Pleurotus florida)," Journal of Food Engineering, vol. 39, no. 3, pp. 255-260, Feb. 1999.

[26] S. M. A. Razavi and M. Taghizadeh, "The specific heat of pistachio nuts as affected by moisture content, temperature, and variety," Journal of Food Engineering, vol. 79, no. 1, pp. 158-167, Mar. 2007.

[27] B. G. Jaramillo, "Propiedades físicas del café pergamino. Thesis M.Sc. (Physic)," Universidad Nacional de Colombia, 1989.

[28] R. E. C. Montoya, "Optimización operacional del secador intermitente de flujos concurrentes para café pergamino. Thesis M. Sc (Operations Research)," Universidad Tecnológica de Pereira, 1989.

[29] BRASIL, "Regras para análise de sementes," Brasilia, 2009.

[30] H. Ramaswamy, G. Vijaya Raghavan, A. Chakraverty, and A. Mujumdar, Eds., Handbook of Postharvest Technology. CRC Press, 2003.

[31] J. P. Holman, Heat Transfer, 9 th. New York: , 2001.

[32] A. Regazzi, "Teste para verificar a identidade de modelos de regressão e a igualdade de parâmetros no caso de dados de delineamentos experimentais.," Revista Ceres, vol. 46, pp. 383-409, 1999.

[33] V. Chandrasekar, "Physical and Thermal Properties of Coffee," Journal of Agricultural Engineering Research, vol. 73, no. 3, pp. 227-234, Jul. 1999.

[34] H. Kocabiyik, B. Kayisoglu, and D. Tezer, "Effect of Moisture Content on Thermal Properties of Pumpkin Seed," International Journal of Food Properties, vol. 12, no. 2, pp. 277-285, Mar. 2009.

[35] B. Kayisoglu, H. Kocabiyik, and B. Akdemir, "The effect of moisture content on the thermal conductivities of some cereal grains," Journal of Cereal Science, vol. 39, no. 1, pp. 147-150, Jan. 2004.

[36] A. K. Mahapatra, Y. Lan, and D. L. Harris, "Influence of Moisture Content and Temperature on Thermal Conductivity and Thermal Diffusivity of Rice Flours," International Journal of Food Properties, vol. 14, no. 3, pp. 675-683, Mar. 2011. 